\title{
ON A COLLECTION OF RECENT CRINOIDS FROM THE PHILIPPINE ISLANDS.
}

\author{
By Austin Hobart Clark,
}

Collaborator, Division of Marine Invertebrates, U. S. National Museum.

The second consignment of crinoids received from the United States Fisheries steamer Albatross, now working among the Philippine Islands, proves to be a collection of very considerable interest, and well worth a separate report. The first consignment included fifty-two species, four of which, however, were laid aside until additional material could be obtained for comparison; these are described herein. The present lot contains twenty-nine species, fifteen of which (or about half) were not met with before, while of the species represented in the first lot thirty-one (more than half) are not included. A few of the Challenger species yet remain to be rediscovered, while several genera, known from both north and south of the islands, have not as yet been discovered there.

Endoxocrinus alternicirrus has been rediscovered for the first time, and Hypalocrinus naresianus, dredged by the Challenger and the Siboga, has been again found. Metacrinus wyvillii, known from the Kermadec and $\mathrm{Ki}$ islands, proves to occur also in the Philippines, while a peculiar comatulid type, first found off the Meangis Islands and later at South Africa, is represented in the collection.

\section{Family COMASTERIDA.}

\section{Genus COMAStER L. Agassiz. \\ COMASTER SENTOSA (P. H. Carpenter).}

Obtained at station 5249, Rakiputan Strait, between the northern end of Samal Island and the west coast of Davao Bay; 23 fathoms.

COMASTER MULTIRADIATA (Linnæus).

A single specimen from station 5249, Rakiputan Strait, between the northern end of Samal Island and the west coast of Davao Bay; 23 fathoms; has 20 arms (all the II $\mathrm{Br}$ series present), with 
oblong and strongly overlapping brachials; but the cirrus joints agree with those given for $C$. multiradiata by Carpenter.

A critical study of a very large series shows that Comatula fimbriata, Actinometra borneensis, and Actinometra coppingeri should all be referred to the Linnæan Asterias multiradiata.

Other specimens were obtained at stations 5161, between Simaluc Island and Tawi Tawi; 16 fathoms; and 5165, south of San Gasanga Island (Tataan group); 9 fathoms.

\section{Genus PHANOGENIA Lovén.}

PHANOGENIA MULTiBRACHIATA (P. H. Carpenter).

This species was secured a station 5248, Rakiputan Strait, between the northern end of Samal Island and the west coast of Davao Bay; 18 fathoms; station 5249, same locality; 23 fathoms; and station 5254, same locality; 21 fathoms.

PHANOGENIA CARPENTERI (A. H. Clark).

One specimen was dredged at station 5153, east of Port Dos Amigos, Tawi Tawi; 49 fathoms.

This is the species which was described by Prof. Johannes Miiller under the name of Alecto multifida, which name, however, he explicitly states to be a substitute for multiradiata Lamarck, not multiradiata Goldfuss. The elements of the III $\mathrm{Br}$ series are united by synarthry, and this led Doctor Carpenter to place the species in his "Parvicirra group," corresponding, in part, to the genus Comanthus; but all except the II $\mathrm{Br}$ series, which are $4(3+4)$, are 2 , a condition quite unknown in Comanthus, the proximal pinnules are slender instead of stout, and terminal combs occur at intervals along the middle and distal pinnules; these combs also are abrupt, with a few long, curved teeth. In spite of the synarthrial instead of syzygial union of the III $\mathrm{Br}$ and IV $\mathrm{Br}$ series, the affinities of this form are distinctly with the members of the genus Phanogenia as restricted, and to that genus it must be assigned.

The specimen at hand has about forty arms.

PHANOGENIA MINIMA, new species.

Centro-dorsal stellate, without cirri; radials entirely visible, trapezoidal, proximally twice, distally three times (or rather more), as broad as long; I $\mathrm{Br}_{1}$ entirely free laterally, four times as broad as long, decreasing slightly in diameter anteriorly; $\mathrm{I} \mathrm{Br}_{2}$ (axillary) broadly pentagonal, twice as broad as long; II $\mathrm{Br} 4(3+4)$, rarely 2 ; III $\mathrm{Br} 2(1+2)$; IV $\mathrm{Br} 2(1+2)$, but rarely present.

About forty arms $70 \mathrm{~mm}$. long; brachials and pinnules as in $P$. gracilis, but proportionately more slender and delicate. 
Color.-Chrome yellow, with numerous longitudinal narrow lines on the radial and division series, and transverse lines on the arms, of dark brown.

Type.-Cat. No. 25469, U.S.N.M., from Albatross station 5108; west of Nasugbu Point, central Luzon (east of Simo Bank); 16 fathoms.

This delicate little species appears to be quite distinct from any of those heretofore described; the absence of regular division series beyond the III Br, these last being $2(1+2)$, are sufficient to distinguish it at once. Though very small, the type-specimen has the appearance of being fully developed.

PHANOGENIA DELICATA, new species.

Centro-dorsal large, discoidal, with a broad flat polar area $5 \mathrm{~mm}$. in diameter; cirrus sockets in a single, slightly irregular, marginal row.

Cirri XHII-XIX, 24-25, moderately stout, $20 \mathrm{~mm}$. to $25 \mathrm{~mm}$. long; first joint about twice as broad as long, the following gradually increasing in length to the fourth or fifth, which is as long as broad; next three or four joints one-third to one-half again as long as broad; following joints decreasing in length, the terminal fourteen or fifteen being about twice as broad as long; the second and following joints have their distal dorsal edges slightly prominent; after the seventh or eighth, which is a well-marked transition joint, the distal dorsal edge becomes strongly produced and finely serrate, this production very gradually narrowing anteriorly, at the same time gradually becoming crescentic, and gaining in height; the antepenultimate joint bears a subterminal transverse ridge, bending forward on each side as it decreases in height; opposing spine small, median, erect, transversely elongate, not reaching one-fourth the dorso-ventral diameter of the penultimate joint in height; terminal claw longer than the penultimate joint, moderately stout, evenly tapering, and moderately and evenly curved.

Ends of the basal rays visible as small tubercles in the angles of the calyx, bridging over the narrow clefts between the centro-dorsal and the primary division series; radials only very slightly visible over the ends of the basal rays; $\mathrm{I} \mathrm{Br}_{1}$ almost entirely, or quite, concealed, very short, almost entirely united laterally; $\mathrm{I} \mathrm{Br}_{2}$ (axillary) broadly pentagonal, twice as broad as long, the anterior angle rather produced, the lateral edges free; II $\mathrm{Br} 4(3+4)$, well separated laterally; II $\mathrm{Br}_{2}$ united for the proximal two-thirds, separated by a broad U-shaped gap distally; III Br 2 , very rarely $4(3+4)$.

Arms thirty or thirty-one, slender, $70 \mathrm{~mm}$. to $80 \mathrm{~mm}$. long; first two brachials approximately equal, slightly wedge-shaped, about twice as broad as the median length, the first almost entirely united 
interiorly; third and fourth brachials (syzygial pair) half again to twice as broad as long, oblong; next three brachials oblong, about twice as broad as long, then becoming wedge-shaped, almost triangular, half again as broad as long, after the proximal third of the arm becoming gradually less obliquely wedge-shaped, though remaining of about the same proportionate length, and in the terminal portion of the arm becoming wedge-shaped, and as long as or longer than broad. The elements of the division series have everted and prominent, finely spinous, distal ends; the brachials have strongly produced and overlapping, finely spinous, distal ends. Syzygies occur between the third and fourth brachials, again between the eleventh and twelfth or twelfth and thirteenth, and distally at intervals of four oblique muscular articulations.

Disk $13 \mathrm{~mm}$. in diameter, with a few scattered calcareous granules about the central anal tube; mouth marginal and radial.

$P_{D} 15 \mathrm{~mm}$. long, slender, with forty joints, all approximately as long as broad; terminal comb arising suddenly, with seven teeth, triangular, longer than broad, basally in apposition, rather longer than the diameter of the joints which bear them, rather strongly incurved; $\mathrm{P}_{1}$ similar, slightly less stout basally, equal in length or slightly longer; $\mathrm{P}_{2}$ small and weak, $6 \mathrm{~mm}$. long; $\mathrm{P}_{3}$ similar, but $5 \mathrm{~mm}$. long (twenty joints); $\mathrm{P}_{4} 6 \mathrm{~mm}$. or $7 \mathrm{~mm}$. long, considerably stouter than the two preceding pinnules, with the distal ends of the joints strongly produced, and bearing a genital gland; following pinnules slightly stouter, with larger genital glands, and slowly increasing in length; distal pinnules very slender, about $9 \mathrm{~mm}$. long, with about twenty joints, the first two short, then increasing in length to about twice as long as broad and decreasing again in the terminal portion.

Color (in spirits).-White, the arms beyond the basal portion with broad broken lateral lines, and dorsal bands, of violet; cirri white, with occasional bands of light violet.

Type.-Cat. No. 25463, from Albatross station 5153; east of Port Dos Amigos, Tawi Tawi; 49 fathoms.

Genus COMATULA Lamarck.

COMATULA PECTINATA (Linnæus).

One specimen from station 5152; off Tawi Tawi; 34 fathoms. 


\section{Genus COMATELLA A. H. Clark. COMATELLA NIGRA (P. H. Carpenter).}

This species was obtained at station 5253; Rakiputan Strait, between the northern end of Samal Island and the west coast of Davao Bay; 28 fathoms. ${ }^{a}$

\section{Genus COMANTHUS A. H. Clark.}

\section{COMANTHUS NOBILIS (P. H. Carpenter).}

Specimens were obtained at station 5249; Rakiputan Strait, between the northern end of Samal Island and the west coast of Davao Bay; 23 fathoms.

Station 5250; same locality; 23 fathoms.

Station 5253; same locality; 28 fathoms; and

Station 5254; same locality; 21 fathoms.

The examples from stations 5249 and 5250 , and one of those from station 5254, have each two well-developed cirri.

\section{COMANTHUS BRIAREUS (Bell).}

I have recently been able to study a large series of specimens of this and allied species, and have succeeded in dividing them up into certain specific groups which appear to be circumscribed by definite and well-defined characters, and which will, I believe, stand the test of future investigations.

Briareus was first described by Bell from Port Denison, Australia, but he entirely overlooked its very obvious affinities, placing it in the genus "Antedon," between two species of Zygometra. The division series subsequent to the III $\mathrm{Br}$ are described as "two joints, no syzygy," but in the figure most of them are $4(3+4)$. Carpenter called attention to both of these errors in 1888, and at the same time described a supposedly new species, divaricata, from Banda; divaricata differs from briareus only in having the centro-dorsal small and stellate, with no trace of cirri, this being in briareus a thin disk with from fifteen to twenty partially developed cirri. The present series shows all variations between the two extremes, and it therefore becomes necessary to consider the two identical. The type of divarcata is slightly smaller than that of briareus, though more developed; but

${ }^{a}$ Under the name of Antedon bassett-smithi Professor Bell has described (and, fortunately, figured) a specimen of Comatella stelligera from the Macclesfield Bank, just west of the Philippine Islands. He refers this supposed new species to Carpenter's " Spinifera group," and discourses at great length upon the "extraordinary divergences exhibited by the syzygies of this species." Had the "species" been referred to the "Stelligera group" of "Actinometra," instead of to the "Spinifera group" of "Antedon," this peculiarity, as well as all the other supposed peculiarities, would have been found to be quite normal. Being now correctly identified, there is no longer any danger that "Antedon" bassettsmithi "will severely shake our faith in the value of the site of the syzygy as an aid in specific diagnosis." 
the difference is not great, and the size at which any given comasterid may become mature is always variable. Carpenter's magnifica, from the Philippine Islands, is very close to briareus, representing merely a somewhat more advanced stage along the same phylogenetic line, and many specimens of the latter approach it more or less; but magnifica is sufficiently well marked off to retain its present status as a distinct species.

The Philippine specimens referred to briareus were compared with a typical Australian example and no differences were found.

The Albatross dredged Comanthus briareus at station 5138; between Jolo and Pangasinan islands; 19 fathoms.

Station 5142; north of Jolo (town) ; 21 fathoms.

Station 5147; off Balinpongpong Island (south of Jolo); 21 fathoms.

Station 5148; Rakiputan Strait; between the north end of Samal Island and the west coast of Davao Bay; 18 fathoms.

Station 5249; same locality; 23 fathoms; and

Station 5254; same locality; 21 fathoms.

COMANTHUS POLYCNEMIS, new species.

In my previous list I referred, rather doubtfully, to Comanthus alternans, a specimen resembling $C$. briareus in all respects, except that the division series distal to the II $\mathrm{Br}$ are 2 until the last division series is reached, which is usually $4(3+4)$. The present collection contains numerous examples of the same form which appears to be quite constant, and I therefore propose to recognize it under the name of Comanthus polycnemis. It may be diagnosed as follows:

Centro-dorsal pentagonal or stellate, with no trace of cirri; general build and proportions as in $C$. briareus; rays dividing four to six (usually four or five) times; II $\mathrm{Br} 4(3+4)$; subsequent divisions 2 , except that the outermost divisions, especially on the outer side of each III Br series, are usually $4(3+4)$.

The scarcity of $4(3+4)$ division series, which, though always present, are confined to the outer parts of the rays, distinguish this species at once from all others. Bell's variabilis, and the multifida of Müller and Carpenter, placed by the latter in the "Parvicirra group," and therefore presumably considered by him as near briareus, belong in reality to the genius Phanogenia and are near $P$. typica.

Type.-Cat. No. 25467, U.S.N.M., from Albatross station 5249; Rakiputan Strait, between the northern end of Samal Island and the west coast of Davao Bay; 23 fathoms.

The Albatross dredged this species at-

Station 5139; between Jolo and Pangasinan Islands; 20 fathoms.

Station 5147; off Balinpongpong Island (south of Jolo); 21 fathoms. 
Station 5248; Rakiputan Strait, between the northern end of Samal Island and the west coast of Davao Bay; 18 fathoms.

Station 5249; same locality; 23 fathoms.

Station 5250; same locality; 23 fathoms.

Station 5251; same locality; 20 fathoms.

Station 5252; same locality; 28 fathoms.

Station 5253; same locality; 28 fathoms.

Station 5254; same locality; 21 fathoms.

There are also specimens with no definite locality given.

One of the specimens from station 5249 is four rayed.

COMANTHUS DUPLEX (P. H. Carpenter).

A single specimen was secured at station 5252; Rakiputan Strait, between the northern end of Samal Island and the western coast of Davao Bay; 28 fathoms.

COMANTHUS ROTALARIA (Lamarck).

This species was found at station 5218, east of the northern end of Burias Island (south of Luzon); 20 fathoms.

Station 5248; Rakiputan Strait, between the northern end of Samal Island and the western coast of Davao Bay; 18 fathoms.

Station 5253; same locality; 28 fathoms; and

Station 5254; same locality; 21 fathoms.

COMANTHUS ALTERnANS (P. H. Carpenter).

One specimen was dredged at station 5252; Rakiputan Strait, between the northern end of Samal Island and the western shore of Davao Bay; 28 fathoms; and another at station 5254; same locality; 21 fathoms.

\section{Family HIMEROMETRID $\mathbb{E}$.}

\section{Genus PONTIOMETRA A. H. Clark.}

PONTIOMETRA INSPERATUS, new species.

Centro-dorsal hemispherical, the dorsal pole small, slightly convex; cirrus sockets arranged roughly in three alternating rows, more or less crowded.

Cirri XX, 41-52, $30 \mathrm{~mm}$. long, stout, but tapering in the distal half, and comparatively slender at the tip; first joint three times as broad as long, second and third twice as broad as long, the following gradually increasing in length to about the seventh, which is about one-third broader than long; next three or four similar, the joints then gradually decreasing in length, those in the distal third of the cirrus being uniformly twice as broad as long; sixth to eighth and following joints with the distal dorsal edge everted in the shape of an open $\mathbf{V}$-shaped ridge, composed of an apical round tubercle, and two lateral more or less elongate tubercles; distally this ridge gradually becomes less and less V-shaped, composed of four or five tubercles, 
the apical tubercle, however, remaining in the same position, and therefore occupying a place below the center of the now almost straight tubercular ridge; as the joints decrease in length distally, the apical tubercle gradually disappears, and the transverse ridge moves gradually to a median position; on becomang median, it at first has usually four tubercles, this being later reduced to three, while beginning on about the fifteenth from the end there are only two, the last three or four joints before the penultimate bearing only a single median tubercle; opposing spine comparatively large, arising from the entire dorsal surface of the joint, the apex subterminal, equal to about half the diameter of the penultimate joint in height; terminal claw somewhat longer than the penultimate joint, rather stout, and strongly curved.

Ends of the basal rays not visible; radials short in the median line, but extending far up into the angles of the calyx, reaching the disk, and separating the bases of the $\mathrm{I} \mathrm{Br}_{1} ; \mathrm{I} \mathrm{Br}_{1}$ slightly trapezoidal, about twice as broad basally as long, very widely separated laterally, well rounded dorsally; $\mathrm{I} \mathrm{Br}_{2}$ (axillary) pentagonal, about as long as broad; II $\mathrm{Br} 2$, one series only being present.

Arms eleven in number (in the type), very widely separated. All the arms are broken off at the syzygy between the third and fourth brachials. First brachial slightly wedge-shaped, half again as broad as long, interiorly united for the anterior half or two-thirds, diverging distally as approximately a right angle; second brachial nearly square; third (hypozygal) oblong, three times as broad as long.

$\mathrm{P}_{1}$ slender, $15 \mathrm{~mm}$. long, evenly tapering, with twenty to twentyfive joints, the first twice as broad as long, the second and third squarish, the following about twice as long as broad, shorter terminally.

Color.-Purplish brown.

Type-Cat. No. 25468, U.S.N.M., from Albatross station 5145; off Jolo town; 23 fathoms.

\section{Genus CENOMETRA A. H. Clark.}

CENOMETRA DELICATA, new species.

Centro-dorsal discoidal, the polar area slightly concave; cirrus sockets marginal, arranged in two closely crowded alternating rows.

Cirri XIX, 31-33, $20 \mathrm{~mm}$. long, comparatively slender; first joint short, the remainder subequal, about twice as broad as long; joints somewhat flattened dorsally, after the tenth bearing very small blunt paired median dorsal tubercles; opposing spine triangular, arising from the entire surface of the penultimate joint, blunt, the apex median in position; terminal claw about as long as the penultimate joint, rather stout and strongly curved.

Ends of the basal rays visible as flattened tubercles in the angles of the calyx, but difficult to differentiate from the centro-dorsal; 
radials visible, but short; slightly divergent distally; $\mathrm{I} \mathrm{Br}_{1}$ trapezoidal, decreasing slightly in diameter anteriorly, proximally about two and one-half times as broad as long; $\mathrm{I} \mathrm{Br}_{2}$ (axillary) broadly pentagonal, about twice as broad as long, the lateral edges about as

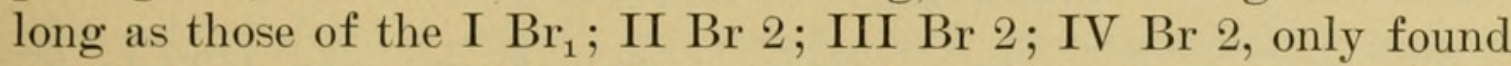
on the outer side of the I $\mathrm{Br}$ series; all the joints to and including the second brachial with prominent lateral processes, the outer edges of which form a line parallel to the axis of the division series.

Thirty-five arms (in the type) $85 \mathrm{~mm}$. long, more slender than in the other species of the genus; brachials as in $C$. unicomis, but proportionately slightly longer.

The pinnules are in general like those of $C$. unicornis, but $\mathrm{P}_{2}$ is much more slender, $9 \mathrm{~mm}$. long, with sixteen or seventeen joints, the first nearly twice as long as broad, becoming squarish on the third, and then gradually becoming about one-third longer than broad; from the fourth onward the distal dorsal edge of the joints is strongly produced, standing out in the form of a coarsely spinous crescentic ridge.

Color.-Deep violet, the cirri, $\mathrm{P}_{2}$, and the dorsal side of the other pinnules, bright yellow.

Type.-Cat. No. 25465, U.S.N.M., from Albatross station 5248; Rakiputan Strait, between the northern end of Samal Island and the west coast of Davao Bay; 18 fathoms.

Another specimen, entirely deep violet, with thirty-four arms, was dredged at station 5249; same locality; 23 fathoms.

CENOMETRA UNICORNIS (A. H. Clark).

Two fragmentary specimens from station 5108; west of Nasugbu Point (off Simo Bank) central Luzon; 16 fathoms.

\section{Genus STEPHANOMETRA A. H. Clark.}

STEPHANOMETRA TENUIPINNA (Hartlaub).

One mutilated specimen was dredged at station 5174; off Jolo town; 20 fathoms.

Genus CYLLOMETRA A. H. Clark.

CYLLOMETRA MANCA (P. H. Carpenter).

One specimen from station 5154; off Tawi Tawi (between Simaluc and Tawi Tawi); 12 fathoms; and others from station 5212; off Masbate; 80 fathoms.

Genus Oligometra A. H. Clark.

Oligometra PUlChella A. H. Clark.

One small mutilated specimen from station 5248; Rakiputan Strait, between the northern end of Samal Island and the west coast of Davao Bay; 18 fathoms. 


\title{
Family TROPIOMETRIDA.
}

\section{Genus CALOMETRA A. H. Clark.}

CALOMETRA CARDUUM A. H. Clark.

\begin{abstract}
One fine specimen from station 5166; off Simonor Island; 97 fathoms.
\end{abstract}

\section{Genus PTilometra A. H. Clark.}

PTILOMETRA PULCHERRIMA, new species.

Centro-dorsal large, columnar, the sides parallel, terminated by a group of five large tubercles each radial in position, arising from an otherwise flat polar area; small circular space bounded by the ends of these tubercles light in color, this light color extending in interradial lines between the summits of the tubercles and thence to the periphery of the polar area; cirrus sockets arranged in ten columns of three or four each, the radial areas being separated from each other by a low, rounded ridge, and the pairs of columns in each radial area being separated by a broad, shallow groove about twice as broad as the rounded interradial ridges. The centro-dorsal is $5 \mathrm{~mm}$. long and $6 \mathrm{~mm}$. in diameter.

Cirri long and slender, XXXV, 80-85 (the less developed as few as $68), 75 \mathrm{~mm}$. to $80 \mathrm{~mm}$. long; first joint short, second about twice as broad as long, the following gradually increasing in length to the sixth or seventh, which is as long as broad; following fifteen to twenty joints between one-third and one-half again as long as broad, then very slowly decreasing in length, the terminal thirty to thirty-five joints being about twice as broad as long; the cirri are somewhat compressed distally; after the seventeenth to the twentieth joint the median part of the distal dorsal edge begins to project as a sharp and slender spine, directed diagonally forward; this spine gradually increases in length, at the same time arising from more and more of the dorsal surface of the joints, on the short distal joints arising from their entire dorsal surface, with a slightly convex proximal and more strongly concave distal edge, equaling in height about one-half the vertical diameter of the joints; terminal eight or ten joints tapering rather rapidly, at the same time increasing slightly in proportionate length, so that the antepenultimate and penultimate joints are very small and about as long as broad; opposing spine equal in length to the diameter of the penultimate joint, blunt, the distal edge forming a straight line with the distal edge of the penultimate joint, arising from nearly or quite the whole of the dorsal surface of that joint; terminal claw slightly longer than the penultimate joint, comparatively stout and strongly curved.

Disk naked; all but one of the ambulacra (which divides immediately) are given off in well-separated pairs, so that nine ambulacral 
grooves reach the mouth; brachial ambulacra naked; pinnule ambulacra with small but well developed side and covering plates.

Ends of the basal rays visible as small tubercles in the angles of the calyx; radials short, of approximately uniform width all around the calyx, slightly convex proximally and correspondingly concave distally; $\mathrm{I} \mathrm{Br}_{1}$ oblong, three times as broad as long, in close apposi-

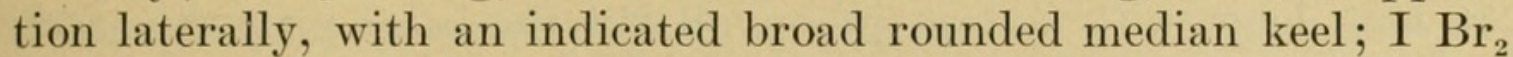
broadly pentagonal, two and one-half times as broad as long, the lateral edges about half as long as those of the $\mathrm{I} \mathrm{Br}_{1}$, in close lateral apposition and sharply flattened; II $\mathrm{Br} 2$, resembling the I $\mathrm{Br}$, but proportionately slightly longer, with the same indicated broadly rounded median keel, sharply flattened laterally and in close apposition.

Twenty arms $100 \mathrm{~mm}$. long; first two brachials slightly wedgeshaped, about twice as broad as long, sharply flattened and in close apposition exteriorly, the first closely united interiorly, the second in close apposition and flattened interiorly; third and fourth brachials (syzygial pair) oblong, about one-third broader than long; next four or five brachials oblong, about three times as broad as long, then becoming wedge-shaped, and after the twelfth or fifteenth triangular, two and one-half times as broad as long, in the terminal part of the arm wedge-shaped again and slightly longer, the arm ending abruptly with six or seven very small and short brachials, and curving inward between the terminal pinnules, which exceed the arm in length by $4 \mathrm{~mm}$.; arms broadly convex dorsally in their basal portion (the first seven or eight brachials sharply "wall-sided"), very gradually becoming narrower, and distally strongly carinate; at about the twelfth or fifteenth brachial a broadly rounded median keel begins to be indicated; this gradually narrows distally, and on the twentieth to the twenty-fifth the median portion of the distal edge begins to be slightly prominent; this increases slowly in extent at the same time narrowing, so that brachials in the outer half of the arm are bluntly carinate, with the median portion of the distal edge produced, and in the terminal portion sharply carinate, with prominent overlapping spines.

$\mathrm{P}_{1} 8 \mathrm{~mm}$. long, strongly prismatic, slightly less stout than the succeeding pinnules, with sixteen joints, the first short, the second and third squarish, the remainder very slightly longer than broad, becoming about one-third again as long as broad distally. $\mathrm{P}_{2} 12.5$ $\mathrm{mm}$. long, with nineteen joints, the first twice as broad as long, the second squarish, the remainder very slightly longer than broad; the more distal joints exhibit a tendency toward a slight production of their distal edges at the prismatic angles; the terminal three or four joints taper rather more rapidly than usual. $\mathrm{P}_{3} 14 \mathrm{~mm}$. long, with seventeen joints, the first twice as broad as long, the second squar-

Proc. N. M. vol. $x x x v I-09-26$ 
ish, then very gradually becoming longer than broad, and twice as long as broad in the terminal portion; the last six joints taper rather rapidly, and the last two joints are minute; from the fourth joint onward small spines are developed on the distal border, on the distal angle of the pinnule, and the last four joints have, in addition, a somewhat longer spine developed on the corresponding interior angle. $P_{4}$ $15 \mathrm{~mm}$. long, with sixteen joints, all but the basal proportionately longer than those of $\mathrm{P}_{3}$, the distal with long spines on their prismatic angles; $\mathrm{P}_{5}$ similar, slightly longer; $\mathrm{P}_{6}$ similar, $17 \mathrm{~mm}$. long; $\mathrm{P}_{10}$ is 19 $\mathrm{mm}$. long, with twenty joints, becoming elongate distally, with long spines at the prismatic angles; in the terminal part of the arms the pinnules slowly decrease in length. The abrupt distal taper gives the pinnules the appearance of having been broken off at the tip and subsequently repaired.

Color--Yellow-brown.

Type.-Cat. No. 25466, U.S.N.M., from Albatross station 5252; Rakiputan Strait, between the northern end of Samal Island and the western shore of Davao Bay; 28 fathoms.

\section{Family THALASSOMETRIDÆ.}

\section{Subfamily THALASSOMETRIN AE.}

\section{Genus STENOMETRA A. H. Clark.}

\section{STENOMETRA ARACHNOIDES, new species.}

Centro-dorsal moderate, columnar, broader basally than long, decreasing slightly in diameter distally, the bare polar area $2 \mathrm{~mm}$. in diameter; cirrus sockets arranged in ten columns of two each, closely crowded.

Cirri XX (XII in the type), 61-65, $30 \mathrm{~mm}$. long; first four joints subequal, averaging twice as broad as long, rather prominently overlapping all around; fifth joint nearly half again as long as broad, a more or less marked transition joint; sixth joint about the same length or slightly shorter; next five joints approximately squarish, then gradually decreasing in length, those in the distal half of the cirrus being twice as broad as long, or even slightly shorter; the fourteenth or fifteenth and following joints bear prominent dorsal spines.

Disk and ambulacra well plated.

Ends of the basal rays visible as dorso-ventrally elongate tubercles in the angles of the calyx; radials concealed, or with the distal, coarsely spinous, margin just visible over the ends of the basal rays;

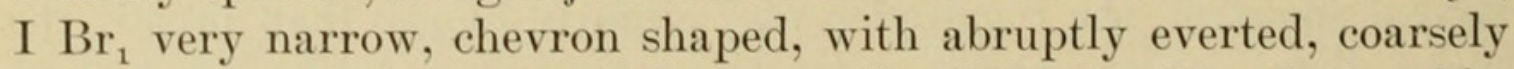
spinous edges, in close apposition laterally; $\mathrm{I} \mathrm{Br}_{2}$ (axillary) rhombic, twice as broad as long, the edges concave, abruptly everted and coarsely spinous all around, a high sharp median keel in the proximal two-thirds. 
Arms ten, but all broken off near the base; first two brachials externally, and second and third internally, sharply flattened laterally; first brachials interiorly united; second brachial large, shieldshaped, deeply incising the very narrow first brachial; first two brachials with more or less everted and coarsely spinous edges; arms with a very narrow, sharp, and moderately high median carination.

The pinnules are essentially as in S. hana.

Color.-Chrome yellow.

Type-Cat. No. 25470, U.S.N.M., from Albatross station 5154; off Tawi-Tawi (between Simaluc and Tawi-Tawi); 12 fathoms.

A much mutilated specimen found in a jar with a specimen of Amphimetra discoidea (and therefore probably taken in shallow water), from Port Denison, Australia, certainly belongs to this genus, and possibly to this species. It is slightly smaller than the type, with the keels less produced, and with the spinous edges of the lower joints less pronounced, differences which are in all probability due to immaturity.

The occurrence in the East Indian region of a littoral species of Thalassometridæ, a family there and elsewhere especially characteristic of the deep-water "Oceanic" faunal division, is a fact of very considerable interest.

CROTALOMETRA, nev genus.

Centro-dorsal large, conical, as long as or longer than broad, the cirrus sockets large, arranged in two columns of usually two each in each radial area.

Cirri X-XX, 60-80, very long and strongly flattened; first five joints short, then longer than broad, becoming short again distally; distal joints with the distal dorsal edge produced; all the joints with the edge all around somewhat prominent.

Ends of basal rays visible as small tubercles in the angles of the calyx; radials short and bandlike, of uniform height, or concealed; I Br of moderate length, rounded dorsally, in close lateral apposition and strongly wall sided, the lateral edges everted.

Ten to twenty arms; II $\mathrm{Br} 4(3+4)$; first two brachials in close lateral contact, and sharply flattened, the lateral edges everted; first four brachials in close apposition and sharply flattened interiorly; arms stout and,rugged; first nine or ten brachials oblong, about twice as broad as long, tubercular; following brachials triangular, about as long as broad, becoming wedge-shaped and somewhat longer than broad terminally. Syzygies occur between the third and fourth brachials, again between the fourteenth-fifteenth to seventeentheighteenth, and distally at intervals of four to ten (usually six or seven) oblique muscular articulations. 
$\mathrm{P}_{1}$ large and stout, but becoming slender distally, strongly flattened exteriorly; following pinnules decreasing rapidly in stoutness, and somewhat in length; distal pinnules stout, strongly prismatic, longer than $\mathrm{P}_{1}$.

Color.-Yellow.

Genotype.-Crotalometra eupedata.

Carpenter's Antedon valida, the systematic position of which has puzzled me greatly, belongs to this genus, and is closely related to C. eupedata, though apparently perfectly distinct; Antedon incerta also should be referred to this genus. The Antedon magnicirra described from South Africa by Professor Bell is likewise a member of this genus, and I have examined two or three additional species from the East Indian region.

CROTALOMETRA EUPEDATA, new species.

Centro-dorsal large, conical, $5 \mathrm{~mm}$. long and $5 \mathrm{~mm}$. broad at the base, the bare polar area forming the apex of the cone; cirrus sockets arranged in ten columns, one at the outer side of each radial area, so that the cirrus columns of adjacent radial areas are in close apposition, the two columns in each area being separated by a space about equal to their own width; one or two cirrus sockets to each column, usually succeeded by one or two obsolete and more or less obliterated ones.

Cirri X-XX, $66,90 \mathrm{~mm}$. long; first three joints two and one-half times as broad as long; fourth twice as broad as long; fifth half again as broad as long; sixth slightly longer than broad; seventh a transition joint, dull in the anterior three-fourths, highly polished and flattened in the distal fourth, not quite twice as long as broad; eighth to eleventh or twelfth joints about twice as long as broad, then gradually decreasing in length, becoming squarish about the twentieth, and twice as broad as long distally; after the fifteenth joint, the distal dorsal edge begins to project slightly, though this is scarcely noticeable until the twentieth is reached, after which it increases in height, becoming more sharply rounded in end view, and arises gradually from the whole dorsal surface of the joint, so that the dorsal profile of the terminal third of the cirrus is strongly serrate; opposing spine a blunt tubercle, the apex subterminal, arising from the whole dorsal surface of the penultimate joint; terminal claw very long and slender, twice as long as the penultimate joint, only slightly curved; all the cirrus joints have the distal ends all around slightly projecting and very finely spinous, making the cirri rough to the touch; this projection is slightly more marked on the ventral side than laterally.

Disk covered with small plates, very thickly set near the ambulacra, but becoming more scattered toward the periphery in the interambulacral areas; disk ambulacra lined with large regular plates; 
plating on brachial and pinnule ambulacra very highly developed; perisome of the arms completely covered with rather large interbrachial plates, so that the arms and pinnules, when the covering plates are closed, are completely encased in a calcareous covering.

Ends of the basal rays visible as small, though prominent, tubercles in the angles of the calyx; radials of uniform width all around the calyx, short, somewhat over four times as broad as long, the anterior edge set with small scattered spines; $\mathrm{I} \mathrm{Br}_{1}$ short, of uniform height, the posterior border convex, the anterior concave, about three times as broad as long, the posterior edge slightly prominent, the lateral edges in very close apposition, and rather prominently everted, the crest of the resultant ridge finely spinous; $\mathrm{I} \mathrm{Br}_{2}$ broadly pentagonal, the lateral edges about as long as those of the $\mathrm{I} \mathrm{Br}_{1}$, about twice as broad as long, the lateral edges everted and finely spinous like those of the $\mathrm{I} \mathrm{Br}_{1}$; like the $\mathrm{I} \mathrm{Br}_{1}$ and the first two brachials it bears a single small rather prominent rounded tubercle near each lateral margin.

Arms ten, stout and rugged, gradually becoming slender distally, $150 \mathrm{~mm}$. long; first brachial longer exteriorly than interiorly, concave anteriorly, the interior edges closely united, the exterior in close apposition, everted and spinous like those of the preceding joints; second brachial about twice as large, irregular in shape, strongly convex posteriorly, in close apposition and strongly flattened with everted and spinous edges, both exteriorly and interiorly; third and fourth brachials (syzygial pair) half again as broad as long, flattened exteriorly and interiorly, the edges less everted than those of the preceding joints; following five brachials approximately oblong, rather strongly tubercular, about three times as broad as long, after the twelfth becoming triangular, about as long as broad, this proportion remaining unchanged until near the arm tips, where the brachials become wedge-shaped, and somewhat longer; the distal edges of the brachials in the outer two-thirds of the arm are overlapping and finely spinous. Syzygies occur between the third and fourth brachials, again between the fourteenth-fifteenth to seventeentheighteenth, and distally at intervals of four to ten (usually six or seven) oblique muscular articulations.

$\mathrm{P}_{1}$ large and very stout, strongly flattened exteriorly, with seventeen or eighteen joints all broader than long; the pinnule tapers rather rapidly after the proximal third, so that the terminal portion is delicate, with very small joints; $\mathrm{P}_{2} 7 \mathrm{~mm}$. long, stout basally, though not nearly so stout as $\mathrm{P}_{1}$, tapering rapidly, so that the distal half is slender; it is composed of fourteen joints, the first three broad, the fourth about as long as broad, the remainder somewhat longer than broad; the first six joints of $\mathrm{P}_{1}$ have the distal side very strongly concave, forming two sharp keels, one external along the 
flattened outer side, the other internal; the external keel is armed with fine spines; the distal joints are prismatic, with the angles somewhat produced; $\mathrm{P}_{2}$ has a similar double carination, but, while the exterior keel is much lower, it persists in a raised and very spinous line to the tip of the pinnule; the ends of the distal joints are much more spinous than in $\mathrm{P}_{1} ; \mathrm{P}_{3} 6 \mathrm{~mm}$. long, more slender than $\mathrm{P}_{2}$, being in about the same proportion to that pinnule as it is to $\mathrm{P}_{1}$, with twelve joints, at first broad, becoming about as long as broad at the fifth, and longer than broad distally; the pinnule is strongly prismatic, the ridges and the distal ends of the joints being spinous; but the two basal keels are only slightly marked; $\mathrm{P}_{4}$ and the following pinnules from $\mathrm{P}_{5}$ onward similar to $\mathrm{P}_{3}$, but slightly more slender, with the joints proportionately slightly longer; distal pinnules $12 \mathrm{~mm}$. long, rather stout, strongly prismatic, with eighteen joints, the first crescentic, the second strongly trapezoidal, about as broad as its greater length, the remainder about half again as long as broad; the external ridge is somewhat produced, and finely spinous.

Color.-Bright yellow, the cirri lighter.

Type.-Cat. No. 25462, U.S.N.M., from Albatross station 5236; off the east coast of Mindanao, north of Lianza Bay; 494 fathoms.

A young specimen with arms $60 \mathrm{~mm}$. long was dredged at Station 5116; north of Maricaban Island (between Luzon and Mindoro); 200 fathoms; it possesses one II Br series of $4(3+4)$.

\section{Genus PARAMETRA A. H. Clark.}

PARAMETRA COMPRESSA (P. H. Carpenter).

One specimen from station No. 5255; off Davao (town) ; 100 fathoms; and another very fine example from station 5166; off Simonor Island; 97 fathoms.

Subfamily CHARITOMHTRIN AE.

\section{Genus PACHYLOMETRA A. H. Clark.}

PACHYLOMETRA LEVIGATA, new species.

Centro-dorsal thick-discoidal or more or less columnar, the polar area flat, $2.5 \mathrm{~mm}$. or $3 \mathrm{~mm}$. in diameter; cirrus sockets arranged in three columns in each radial area, the two outer columns converging distally, usually meeting beyond the middle column; columns usually separated by more or less developed ridges.

Cirri XXX-XXXV, 14-15, $15 \mathrm{~mm}$. long; first two joints about twice as broad as long; third joint about as long as broad; fourth to seventh or eighth half again as long as broad, then gradually decreasing distally, the third and fourth from the end being only 
slightly longer than broad; the terminal joints are again about half again as long as broad; distal ventral ends of the joints slightly prominent; distal dorsal ends of the outer joints sometimes slightly thickened; opposing spine minute, terminally situated, directed obliquely forward, often barely indicated or altogether absent; terminal claw nearly as long as the penultimate joint, moderately slender and moderately curved.

Disk completely covered with a pavement of small plates; brachial and pinnule ambulacra well plated; large irregular plates over the genital glands.

Ends of the basal rays usually visible as dorso-ventrally elongate tubercles in the angles of the calyx, but sometimes quite concealed; radials concealed; $\mathrm{I} \mathrm{Br}_{1}$ usually entirely concealed in the median line, slightly visible over the ends of the basal rays, sometimes visible as a narrow line along the proximal border of the $\mathrm{I} \mathrm{Br}_{2} ; \mathrm{I} \mathrm{Br}_{2}$ rhombic, twice as broad as long, all the sides somewhat incurved, rising in the proximal half to a large rounded tubercle; II Br $4(3+4)$, rarely 2 , in close apposition and strongly flattened laterally.

Arms twelve to fourteen, $100 \mathrm{~mm}$. long; first eight or nine brachials wedge-shaped or almost oblong, about twice as broad as long, more or less tubercular, then becoming triangular, about as long as broad, in the terminal portion of the arm wedge-shaped and-longer than broad. Syzygies occur, in arms springing direct from a I Br axillary, between the third and fourth brachials, again between the fourteenth and fifteenth or fifteenth and sixteenth, and distally at intervals of six to sixteen oblique muscular articulations; in arms springing from a II $\mathrm{Br}$ axillary the first syzygy is between the first and second or second and third brachials.

The pinnules resemble those of $P$. angusticalyx, but the expansion of the genital pinnules is somewhat more marked.

Color.-Yellow.

Type.-Cat. No. 25464, U.S.N.M., from Albatross station 5236; off the eastern coast of Mindanao, north of Lianza Bay; 494 fathoms.

\section{Genus GLYPTOMETRA A. H. Clark.}

GLYPTOMETRA TUBEROSA (P. H. Carpenter).

I tentatively refer to this species a very young specimen from station 5236; off the eastern coast of Mindanao, north of Lianza Bay; 494 fathoms. The lateral eversion of the I Br and lower brachials is very pronounced, and the median carination characteristic of tuberosa is indicated on the I $\mathrm{Br}$ and lower brachials; tubercles, however, have not as yet appeared. This specimen is remarkable for the extraordinary size of the external ends of the basal rays. 
Family ANTEDONID Æ.

\section{Genus IRIDOMETRA A. H. Clark.}

IRIDOMETRA EXQUISITA, new species.

Centro-dorsal hemispherical, nearly covered with cirrus sockets, a very small convex polar area bare.

Cirri XL-L, 14-15, exceedingly slender and thread-like, $10 \mathrm{~mm}$. long; first joint short, second half again to twice as long as broad, the following very greatly elongated, becoming shorter again on the antepenultimate, which is three times as long as broad, and the penultimate, which is twice as long as broad; the latter decreases slightly in diameter distally, and may bear a minute terminal opposing spine, though this is usually absent; terminal claw about three-qtarters the length of the penultimate joint, slender, and slightly curved; the articulations of the joints are greatly expanded, except in the terminal five or six.

Radials even with the edge of the centro-dorsal; $\mathrm{I} \mathrm{Br}_{1}$ short, deeply incised in the median line, in contact basally; $\mathrm{I} \mathrm{Br}_{2}$ (axillary) rhombic, twice as broad as long, the anterior angle produced.

Ten arms, $40 \mathrm{~mm}$. long; first brachial much longer outwardly than inwardly, very deeply incised by the second brachial, barely in contact basally over the anterior angle of the $\mathrm{I} \mathrm{Br}_{2}$; third and fourth brachials (syzygial pair) slightly longer interiorly than exteriorly, about as broad as long exteriorly; next four brachials oblong, about twice as broad as long, then becoming triangular, about as long as broad, after the end of the proximal third becoming obliquely wedgeshaped, rather longer than broad, and very gradually increasing in length distally. Syzygies occur between the third and fourth brachials, again between the ninth and tenth and fourteenth and fifteenth, and distally at intervals of three oblique muscular articulations.

$\mathrm{P}_{1} 6 \mathrm{~mm}$. long, moderately stout basally, becoming slender distally, somewhat stiffened, with thirteen joints; first joint twice as broad as long, second half again as long as broad, third and following three or three and one-half times as long as broad, becoming slightly shorter terminally; $\mathrm{P}_{2}$ similar, but more slender, $3 \mathrm{~mm}$. long, with nine joints, the first twice as broad as long, the second slightly longer than broad, the third twice as long as broad, the remainder greatly elongated; $\mathrm{P}_{3} 2 \mathrm{~mm}$. long, with eight joints, not tapering so rapidly as $\mathrm{P}_{2}$ (therefore appearing somewhat stouter), and bearing a small genital gland in the distal portion; the joints have slightly overlapping distal ends; following pinnules similar; distal pinnules $6 \mathrm{~mm}$. long, similar to those in other species of the genus.

Color (in spirits.) - White, with blotches of brown on the arms and pinnules; perisome brown.

Type.-Cat. No. 25471, U.S.N.M., from Albatross station 5178; north of Tablas Island; 78 fathoms. 
Family PENTACRINITIDA.

\section{Genus ENDOXOCRINUS A. H. Clark. \\ ENDOXOCRINUS ALTERNICIRRUS (P. H. Carpenter).}

Two fine specimens of this interesting species were dredged at station 5236; off the eastern coast of Mindanao, north of Lianza Bay; 494 fathoms; one has thirty, the other thirty-one arms, 115 $\mathrm{mm}$. long from the basals. They agree perfectly with Carpenter's description and figure, and with the Challenger specimen in the U.S. National Museum. The color is a slightly brownish white.

Carpenter included as uncertain Challenger station 210, off Panglao and Siquijor (375 fathoms), in his list of localities; the rediscovery of the species in the Philippine Islands suggests that he was right in referring his unlabeled specimens to this station.

\section{Genus HYPALOCRINUS A. H. Clark.}

\section{HYPALOCRINUS NARESIANUS (P. H. Carpenter).}

Three specimens, each with arms about $150 \mathrm{~mm}$. long, were secured at station 5236; off the eastern coast of Mindanao, north of Lianza

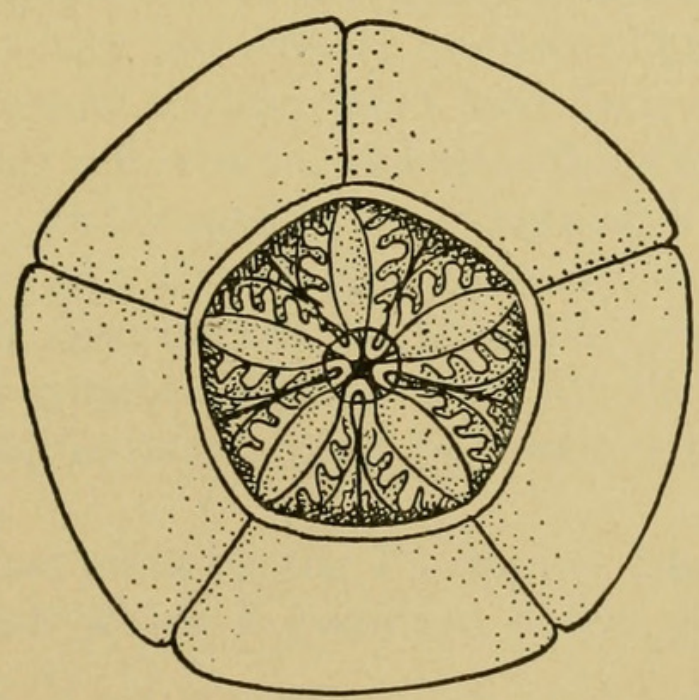

RADIALS, BASALS, AND INFRABASALS OF HYPALOCRINUS NARESIANUS,

Bay; 494 fathoms. They agree perfectly with a specimen at hand from the Challenger collection which possibly was taken off Panglao and Siquijor in 375 fathoms. The peculiar dorso-ventral flattening of the short proximal cirrus joints, and the double dorsal tubercles on the more distal joints, characteristic of the genus, are well marked. The terminal $30 \mathrm{~mm}$. to $35 \mathrm{~mm}$. of the arms have only rudimentary pinnules, so that the arms present the same curious "rat-tailed" appearance considered by Carpenter as especially characteristic of Metacrinus. This condition is exhibited by the two specimens figured by Prof. Döderlein which were obtained by the Siboga off Celebes; 
but in the two Challenger specimens I have examined the arm tips are broken off, as delineated in all Carpenter's figures.

One of the specimens was dissected to determine the presence or absence of infrabasals. They were found to be present, resembling closely those of Isocrinus decorus.

Genus METACRINUS P. H. Carpenter.

METACRINUS WYVILLII P. H. Carpenter.

One broken specimen from station 5236; off the eastern coast of Mindanao, north of Lianza Bay; 494 fathoms.

It agrees well with a specimen taken near the Kermadec Islands in 630 fathoms, in the U. S. National Museum. 


\section{$2 \mathrm{BHL}$ Biodiversity Heritage Library}

Clark, Austin Hobart. 1909. "On a collection of Recent crinoids from the Philippine Islands." Proceedings of the United States National Museum 36(1673), 391-410. https://doi.org/10.5479/si.00963801.36-1673.391.

View This Item Online: $\underline{\text { https://www.biodiversitylibrary.org/item/53526 }}$

DOI: https://doi.org/10.5479/si.00963801.36-1673.391

Permalink: https://www.biodiversitylibrary.org/partpdf/52548

\section{Holding Institution}

Smithsonian Libraries

\section{Sponsored by}

Smithsonian

\section{Copyright \& Reuse}

Copyright Status: Public domain. The BHL considers that this work is no longer under copyright protection.

This document was created from content at the Biodiversity Heritage Library, the world's largest open access digital library for biodiversity literature and archives. Visit BHL at https://www.biodiversitylibrary.org. 